\author{
Katerina Pavenski \\ Gregory M. T. Hare \\ C. David Mazer
}

\section{Erythropoietic neuroprotection: Holy Grail or potential to fail?}

Received: 17 May 2011

Accepted: 17 May 2011

Published online: 16 July 2011

(C) Copyright jointly held by Springer and ESICM 2011

This editorial refers to the article available at doi:10.1007/s00134-011-2303-4.

\section{K. Pavenski}

Department of Laboratory Medicine,

Saint Michael's Hospital, Toronto, ON, Canada

\section{K. Pavenski}

Department of Pathobiology and Laboratory Medicine,

University of Toronto, Toronto, ON, Canada

G. M. T. Hare · C. D. Mazer ( $)$

Department of Anesthesia, The Keenan Research Center in the Li Ka Shing Knowledge Institute of Saint Michael's Hospital, University of Toronto, 30 Bond St., Toronto, ON M5B 1W8, Canada

e-mail: mazerd@smh.ca

Tel.: +1-416-8645825

Fax: +1-416-8646014

G. M. T. Hare - C. D. Mazer

Department of Physiology, University of Toronto,

Toronto, ON, Canada

In this issue of Intensive Care Medicine, Simon et al. [1] report that pretreatment with a carbamylated erythropoietin fusion protein (cEPO-FC) is as effective as recombinant human EPO (rhEPO) in ameliorating spinal cord injury in a well-established porcine model of acute spinal cord ischemia and reperfusion. This new fusion protein contains two rhEPO molecules connected by the Fc region of human $\mathrm{IgG}_{1}$. Subsequent carbamylation of the EPO molecule is thought to improve the cytoprotective effects, while reducing side effects including hypertension and thrombosis [2].

\section{EPO and EPO variants}

Since the human EPO gene was cloned in 1985, several variants of the EPO molecule have been developed to improve its pharmacokinetic and pharmacodynamic characteristics and to separate its hemopoietic and neuroprotective properties [3]. Epoietin alpha and beta are rhEPOs and have minimal differences in their structure. A variety of EPO derivatives, including cEPO-FC, which target the erythropoietin receptor (EpoR), and mimetic compounds (such as EPO-peptide AB, helix B peptide and hematide) have been developed. Darbepoietin alpha is a hyperglycosylated analogue of EPO with a four- to fivefold lower erythropoietin receptor binding activity but a threefold longer serum half-life. Epoietin delta has been produced in a human cell line and has a human-type glycosylation pattern. CERA is a PEGylated form of epoietin beta with a long in vivo half-life. In addition, there are alternative means of enhancing endogenous EPO translation by preventing hypoxia-inducible factor- $\alpha$ degradation or GATA2 inhibition, thereby inducing endogenous EPO gene expression.

\section{What is the cellular mechanism of EPO-induced neuroprotection?}

EPO binds a transmembrane homodimeric cytokine I type EpoR complex. EPO and its receptor have been found in hematopoietic and several non-hematopoietic tissues including central nervous system, endothelium, cardiac myocytes, kidney, liver and some solid cancer cell lines [4]. Upon binding with EpoR an intricate series of intracellular signaling pathways are activated via Janus kinase 2 (Jak2) which increases the activity of intracellular mediators including signal transducer and activator of transcription 5 (STAT5), phosphoinositol 3 kinase 
(PI3K), mitogen-activated protein kinase (MAPK), extracellular signal-regulated kinase (ERK) and nuclear factor kappa B (NF- $\kappa$ B) [5-7]. These signaling pathways may promote neuronal survival by a number of putative mechanisms including: (1) neuroprotection, (2) neurogenesis, (3) antiinflammation, (4) angiogenesis and stabilization of neurovascular function, and (5) reduced oxidative stress. The primary endogenous sources of EPO within the central and peripheral nervous systems appear to be astrocytes and Schwann cells, respectively [8]. These cells release endogenous EPO in a paracrine manner that can affect neuronal survival. By contrast, exogenously administered rhEPO must cross the bloodbrain or blood-spinal cord barrier to gain access to the central nervous system, as shown by a number of experimental studies. This has raised the possibility that exogenously administered rhEPO could have a neuroprotective effect in patients suffering from neuronal ischemia.

However, other recent studies have raised questions about the pleiotropic potential of EPO. Swift et al. [9] found that EpoR protein was barely detectable in 66 human tumor cell lines and EpoR signaling in response to rhEPO was not detected in non-erythroid cells. In another related study, surface EpoR was not detectable on the surface of endothelial, cardiac, neuronal or renal cells and there was no evidence of intracellular signaling induced by erythropoiesis-stimulating agents (ESA) despite the addition of very high doses of rhEPO [10]. ESAs did not reproducibly provide cytoprotection to neuronal, cardiac or renal cells or promote angiogenesis in vivo. However, some have postulated that the tissue-protective properties of rhEPO are dependent on the activation of an alternative receptor complex, a heterodimer consisting of EpoR and the common beta receptor [11].

\section{What is the relevance of this study?}

While previous experimental studies have demonstrated the efficacy of cEPO with respect to alleviating spinal cord injury and improving functional outcomes [6], the current study expands upon this finding by demonstrating that cEPO-FC is as effective as rhEPO in a balloon occlusion model of spinal cord ischemia-reperfusion in pigs. This model has a high degree of clinical relevance since it is applicable to the mechanism of spinal cord ischemia and reperfusion that occurs due to aortic crossclamping during aortic aneurysm repair. In this clinical scenario, pretreatment with rhEPO may alleviate the risk of spinal cord injury due to subsequent aortic cross- clamping. The current study assessed short-term outcomes including motor evoked potentials and histological damage. Future studies will need to focus on the longer term neurological outcomes and demonstrate an absence of systemic toxicity, including thrombosis.

\section{Can treatment with cEPO-FC improve neurological outcome without adverse systemic effects?}

In experimental studies, carbamylation of the EPO molecule reduces the binding potential for the erythroid receptor, which is responsible for erythropoiesis, but maintains binding and efficacy at the tissue receptor, which is thought to be responsible for activating cytoprotective mechanisms $[6,11]$. Therefore, cEPO-FC may provide a cytoprotective capacity in the absence of the toxicity associated with systemic EPO therapy. The importance of this potential is emphasized by the paradoxical findings of recent clinical trials with rhEPO: (1) normalizing hematocrit with rhEPO does not necessarily improve survival; [12-14]; (2) high-dose rhEPO is associated with increased thrombosis [13, 15-17]; and (3) in some patient populations (trauma) low-dose rhEPO may improve survival without affecting hematocrit [18]. In addition, early clinical trials produced interesting results in relation to the treatment of stroke $[7,11]$.

These clinical studies raised the possibility that rhEPO could improve important clinical outcomes including neuronal recovery and survival. However, the appropriate timing, dose and formulation of rhEPO are required. To date, human studies have not established a protective role for rhEPO. In the German multicenter stroke trial, rhEPO failed to show any clinical benefit in terms of the Barthel index, modified Rankin scale and NIHSS on day 90, or MRI parameters [19]. Indeed, the mortality rate in the patients receiving rhEPO was higher than in those receiving placebo, especially in those who had been pretreated with thrombolysis. rhEPO has also been investigated in the setting of myocardial ischemia and reperfusion where basic science studies also suggested a cardioprotective role. However, in a recent multicenter human study in patients with acute myocardial infarction, rhEPO failed to reduce the infarct size, but was associated with an increased rate of adverse cardiovascular events [20]. Thus, much further preclinical and clinical research is needed to determine if derivatives of rhEPO such as cEPO-FC can improve long-term neurological outcome without potential side effects including hypertension, thrombosis and mortality. 


\section{References}

1. Simon F, Scheuerle A, Gröger M, Vcelar O, Möller P et al. (2011) Carbamylated erythropoietin-FC fusion protein and recombinant human erythropoietin during porcine spinal cord ischemia/reperfusion injury. Intensive Care Med. doi: 10.1007/s00134-011-2303-4

2. Coleman TR, Westenfelder C, Tögel FE, Yang Y, Hu Z, Swenson L, Leuvenink HG, Ploeg RJ, D'Uscio LV, Katusic ZS, Ghezzi P, Zanetti A, Kaushansky K, Fox NE, Cerami A, Brines M (2006) Cytoprotective doses of erythropoietin or carbamylated erythropoietin have markedly different procoagulant and vasoactive activities. Proc Natl Acad Sci USA 103:5965-5970

3. Siren Al, Fasshauer T, Bartels C, Ehrenreich H (2009) Therapeutic potential of erythropoietin and its structural or functional variants in the nervous system. Neurotherapeutics 6:108-127

4. Testa U (2010) Erythropoietic stimulating agents. Expert Opin Emerg Drugs 15:119-138

5. Digicaylioglu M, Bichet S, Marti HH, Wenger RH, Rivas LA, Bauer C, Gassmann M (1995) Localization of specific erythropoietin binding sites in defined areas of the mouse brain. Proc Natl Acad Sci U S A 92:3717-3720

6. Leist M, Ghezzi P, Grasso G, Bianchi R, Villa P, Fratelli M, Savino C, Bianchi M, Nielsen J, Gerwien J, Kallunki P, Larsen AK, Helboe L, Christensen S, Pedersen LO, Nielsen M, Torup L, Sager T, Sfacteria A, Erbayraktar S, Erbayraktar Z, Gokmen N, Yilmaz O, Cerami-Hand C, Xie QW, Coleman T, Cerami A, Brines M (2004) Derivatives of erythropoietin that are tissue protective but not erythropoietic. Science 305:239-242

7. Rabie T, Marti HH (2008) Brain protection by erythropoietin: a manifold task. Physiology (Bethesda) 23:263-274

8. Keswani SC, Bosch-Marcé M, Reed N, Fischer A, Semenza GL, Höke A (2011) Nitric oxide prevents axonal degeneration by inducing HIF-1dependent expression of erythropoietin. Proc Natl Acad Sci USA 108:4986-4990
9. Swift S, Ellison AR, Kassner P, McCaffery I, Rossi J, Sinclair AM, Begley CG, Elliott S (2010) Absence of functional EpoR expression in human tumor cell lines. Blood 115:4254-4263

10. Sinclair AM, Coxon A, McCaffery I, Kaufman S, Paweletz K, Liu L, Busse L, Swift S, Elliott S, Begley CG (2010) Functional erythropoietin receptor is undetectable in endothelial, cardiac, neuronal, and renal cells. Blood 115:4264-4272

11. Brines M, Cerami A (2005) Emerging biological roles for erythropoietin in the nervous system. Nat Rev Neurosci 6:484-494

12. Drüeke TB, Locatelli F, Clyne N, Eckardt KU, Macdougall IC, Tsakiris D, Burger HU, Scherhag A; CREATE Investigators (2006) Normalization of hemoglobin level in patients with chronic kidney disease and anemia. N Engl J Med 355:2071-2084

13. Pfeffer MA, Burdmann EA, Chen CY, Cooper ME, de Zeeuw D, Eckardt KU, Feyzi JM, Ivanovich P, Kewalramani R, Levey AS, Lewis EF, McGill JB, McMurray JJ, Parfrey P, Parving HH, Remuzzi G, Singh AK, Solomon SD, Toto R; TREAT Investigators (2009) A trial of darbepoietin alfa in type 2 diabetes and chronic kidney disease. N Engl J Med 361:2019-2032

14. Singh AK, Szczech L, Tang KL, Barnhart H, Sapp S, Wolfson M, Reddan D; CHOIR Investigators (2006) Correction of anemia with epoietin alfa in chronic kidney disease. N Engl J Med 355:2085-2098

15. Bennett CL, Silver SM, Djulbegovic B, Samaras AT, Blau CA, Gleason KJ, Barnato SE, Elverman KM, Courtney DM, McKoy JM, Edwards BJ, Tigue CC, Raisch DW, Yarnold PR, Dorr DA, Kuzel TM, Tallman MS, Trifilio SM, West DP, Lai SY, Henke M (2008) Venous thromboembolism and mortality associated with recombinant erythropoietin and darbepoietin administration for the treatment of cancer-associated anemia. JAMA 299:914-924
16. Bohlius J, Wilson J, Seidenfeld J, Piper M, Schwarzer G, Sandercock J, Trelle S, Weingart O, Bayliss S, Brunskill S, Djulbegovic B, Bennett C, Langensiepen S, Hyde C, Engert A. Erythropoietin or Darbepoietin for patients with cancer. Cochrane Database of Systematic Reviews 2006, Issue 3. Art. No.: CD003407. DOI: 10.1002/14651858.CD003407.pub4

17. Rizzo JD, Somerfield MR, Hagerty KL, Seidenfeld J, Bohlius J, Bennett CL, Cella DF, Djulbegovic B, Goode MJ, Jakubowski AA, Rarick MU, Regan DH, Lichtin AE (2008) Use of epoietin and darbepoietin in patients with cancer: 2007 American Society of Hematology/American Society of Clinical Oncology clinical practice guideline update. Blood 111:25-41

18. Corwin HL, Gettinger A, Fabian TC, May A, Pearl RG, Heard S, An R, Bowers PJ, Burton P, Klausner MA, Corwin MJ; EPO Critical Care Trials Group (2007) Efficacy and safety of epoietin alfa in critically ill patients. N Engl J Med 357:965-976

19. Ehrenreich H, Weissenborn K, Prange H, Schneider D, Weimar C, Wartenberg $\mathrm{K}$, Schellinger PD, Bohn M, Becker H, Wegrzyn M, Jähnig P, Herrmann M, Knauth M, Bähr M, Heide W, Wagner A, Schwab S, Reichmann H, Schwendemann G, Dengler R, Kastrup A, Bartels C; EPO Stroke Trial Group (2009) Recombinant human erythropoietin in the treatment of acute ischemic stroke. Stroke 40:e647-e656

20. Najjar SS, Rao SV, Melloni C, Raman SV, Povsic TJ, Melton L, Barsness GW, Prather K, Heitner JF, Kilaru R, Gruberg L, Hasselblad V, Greenbaum AB, Patel M, Kim RJ, Talan M, Ferrucci L, Longo DL, Lakatta EG, Harrington RA; REVEAL Investigators (2011) Intravenous erythropoietin in patients with ST-segment elevation myocardial infarction: REVEAL: a randomized controlled trial. JAMA 305:1863-1872 